\title{
EFFECTIVENESS OF WET CUPPING THERAPY FOR MIGRAINE IN MOJOKERTO, EAST JAVA
}

\author{
Yulianto'), Yufi Aris Lestari'1), Ulul Azmi' ${ }^{1}$, \\ Erik Toga'), Muh. Al Amin²) \\ ${ }^{1)}$ School of Health Sciences Dian Husada, Mojokerto, East Java \\ ${ }^{2)}$ School of Health Sciences Banyuwangi, East Java
}

\begin{abstract}
Background: Cupping therapy is an ancient form of alternative medicine in which a therapist puts special cups on the patient skin for a few minutes to create suction. It is used for various purposes, including to help with pain, inflammation, blood flow, relaxation and well-being, and as a type of deeptissue massage. Wet cupping creates a mild suction by leaving a cup in place for about 3 minutes. The therapist then removes the cup and uses a small scalpel to make light, tiny cuts on your skin. Next, the therapist does a second suction to draw out a small quantity of blood. This study aimed to determine effectiveness of wet cupping therapy for migraine.

Subjects and Method: This was a quasi experiment before and after with no control design conducted in Mojokerto, East Java. A sample of 57 patients with migraine was selected for this study. The dependent variable was migraine pain level. The independent variable was wet cupping therapy. Pain level was measured by visual analog scale (VAS). Pain level before and after cupping therapy were compaired by paired $t$ test.

Results: Pain level of migraine after wet cupping therapy (mean=2.40; $\mathrm{SD}=1.10$ ) was lower than before (mean=9.21; $\mathrm{SD}=1.57$ ), and it was statistically significant $(\mathrm{p}=0.024)$.

Conclusion: Wet cupping therapy is effective to relieve pain of migraine.
\end{abstract}

Keywords: wet cupping therapy, pain, migraine.

\section{Correspondence:}

Erik Toga. School of Health Sciences Banyuwangi, East Java, Indonesia.

Email: eriktoga@sttikesbanyuwangi.ac.id. Mobile: 087857368992.

The 4th International Conference on Public Health Best Western Premier Hotel, Solo, Indonesia, August 29-30, 2018 | 287 https://doi.org/10.26911/theicph.2018.05.01 